\title{
有機溶媒および樹脂中へのナノ粒子の分散
}

\section{Toward Dispersing Nanoparticles in Organic Solvents and Polymers}

\section{飯島 志行 \\ 東京農工大学 大学院工学研究院 \\ ү 184-8588 \\ 東京都小金井市中町 2-24-16}

Motoyuki Iijima

Institute of Engineering, Tokyo University of Agriculture and Technology 2-24-16 Naka-cho, Koganei-city, Tokyo 184-8588. JAPAN
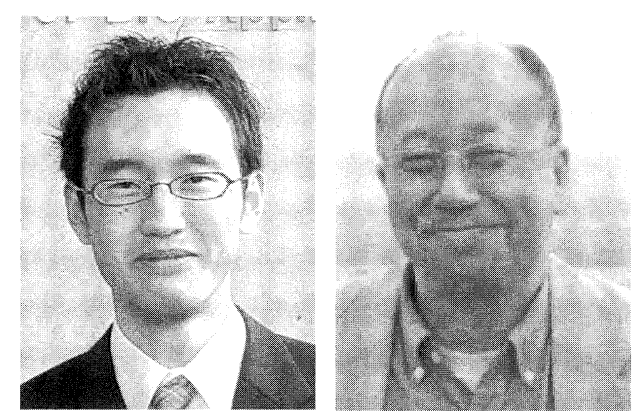

\author{
神谷 秀博 \\ 東京農工大学 大学院工学研究院 \\ ү 184-8588 \\ 東京都小金井市中町 2-24-16
}

Hidehiro Kamiya

Institute of Engineering, Tokyo University of Agriculture and Technology

2-24-16 Naka-cho, Koganei-city,

Tokyo 184-8588. JAPAN

論文要旨：本稿では機能性ナノ粒子をさまざまな有機溶媒やポリマー材料中に均一分散させることを目的 とした微粒子分散プロセスを紹介する。表面修飾プロセスとして主にシランカップリング剂を用いた表面修 飾法と, アニオン性界面活性剂を用いた表面修飾法に着目し, 多段階表面修飾や物理的解砕プロセスを併用 した事例を概説する。シランカップリング剤を用いた表面修飾では, 溶媒種やポリマー種に応じて複数のカッ プリング剂を用いて表面状態を制御するプロセスや，多段階表面修飾によりナノ粒子の分散安定化が可能で ある。また，アニオン性界面活性剤を用いた表面修飾では，疎水鎖と親水鎖に分岐したアニオン性界面活性 甋を用いることで，さまざまな有機溶媒やポリマーへのナノ粒子の分散安定化が可能である。また，これら の表面修飾と物理的解砕処理の組み合わせによるナノ粒子の分散プロセスについても紹介する。

\begin{abstract}
Toward dispersing functional nanoparticles in various solvents and polymers, two kinds of surface modification techniques, such as the use of silane coupling agents and functional anionic surfactants are introduced together with various processing route such as bead milling process. In the case of silane coupling agent usage, tuning the surface properties by using mixed silane coupling agents were effective to control their stability in organic solvents. Furthermore, multiple surface modification routes are introduced to improve their stability in polymers. In case of the use of anionc surfactants, a functional surfactant witch branches into hydrophobic and hydrophilic chains was introduced. Nanoparticles modified by this surfactant were dispersible into many types of solvents/polymers which has completely different properties. Both of these surface modification techniques can also be conducted under bead mill operation system to disperse aggregated nanoparticles in various organic solvents.
\end{abstract}

Key words: nanoparticle, dispersion, stability, surface modification

\section{1 はじめに}

微粒子, とくにその大きさが $1 〜 100 \mathrm{~nm}$ の範用にあ るナノ粒子は，単にサイズが小さいだけではなく，物理 的, 化学的な性質や機能が数 $100 \mathrm{~nm}$ 以上の粒子に比べ て大きく変化するため, さまざまな分野で利用・応用が 検討されており ${ }^{1,2)}$ ，一方でその安全性も議論となって いる ${ }^{3)}$ 。ナノ粒子を材料原料として利用する際には，材 料の調製プロセスにおける粒子分散状態や集合状態が最 終製品の特性・品質に多大な影響を及ぼすため, その制

連絡者：神谷秀博

E-mail :kamiya@cc.tuat.ac.jp
御法は極めて重要な基盤技術である。水溶液系における 液中微粒子分散系では, 粒子分散性に関与する粒子間相 互作用の体系的理論として, 物質間に普遍的に働く van der Waals 引力と界面電気二重層の重なりによる静電相 互作用に関するDLVO 理論 ${ }^{4)}$ に基づく評価・解析法が ある。一方で, ナノ粒子の高濃度分散系や有機溶媒中で はこの理論に基づいた考察のみでは粒子分散制御は困難 である。各種分散片や表面修飾法により粒子表面間相互 作用や溶媒との濡れ性の制御によって分散設計が試みら れているが, 粒子材質・溶媒との組み合わせに加えて, 適切な分子構造や表面修飾プロセスの選定には, ナノ粒 子の有機系溶媒分散体固有の困難さが加わる。たとえば, 
単分散性かつ高分散性に優れるナノ粒子の調製法につい ては，逆ミセル法 ${ }^{5)}$, ポリオール法 ${ }^{6)}$, 有機金属錯体の 熱分解法 ${ }^{7)}$ を一例とした，粒子合成反応と表面保護を 同時に行うプロセスによって調製可能ではある。しかし, 得られたナノ粒子は表面に修飾された有機分子に依存し た溶媒系にしか分散できないため，複数の分散媒を用い ることになる複合材料の調製過程では粒子が著しく凝集 する課題に直面する。本稿ではこのような課題を背景と し，ナノ粒子を有機系溶媒および樹脂に均一分散させる ためのナノ粒子設計法や表面修飾プロセスを紹介する。

\section{2 シランカップリング剤を用いた表面修飾}

シランカップリング剂とは Fig. 1 に示すようにアルコ キシド基と有機官能基 $\mathrm{R}$ から構成される化合物であり, 加水分解反応により生成する $\mathrm{Si}-\mathrm{OH}$ 基が粒子表面に存 在する $\mathrm{OH}$ 基と縮合反応を起こすことによって粒子表面 に固定化される。有機官能基 $\mathrm{R}$ としてはさまざまな構 造のものが市販されており, 微粒子表面の化学構造を高 い自由度をもって制御できるため, 樹脂フィラー表面と 樹脂との接着性向上を目的としたシランカップリング剂 の利用が 1960 年代から報告されている ${ }^{8)}$ 。また, 有機 官能基 R の幅広い選択性から有機溶媒への分散安定化

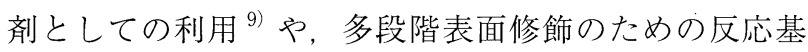
固定化手段 ${ }^{10)}$ として利用が進められている。一方, シ ランカップリング刻は微粒子表面に固定化される過程で Fig. 1 を一例とした複雑な反応過程を経るため, 粒子の 表面修飾時に多くの困難性に直面する。たとえば加水分 解したシランカップリング剤の縮合過程では, シラン カップリング剂が粒子表面の $\mathrm{OH}$ 基と縮合するだけでは なく, 複数のシランカップリング剂同士で縮合反応が進 み, 粗大粒子や強固な粒子間架橋構造が生成し, 粒子の 分散性に多大な影響を及ぼす ${ }^{11)}$ 。Fig. 2 には Agナノ粒

1) $\mathrm{R}-\mathrm{Si}-\left(\mathrm{OCH}_{3}\right)_{3}+3 \mathrm{H}_{2} \mathrm{O} \rightleftarrows \mathrm{R}-\mathrm{Si}-(\mathrm{OH})_{3}+3 \mathrm{CH}_{3} \mathrm{OH}$

2)
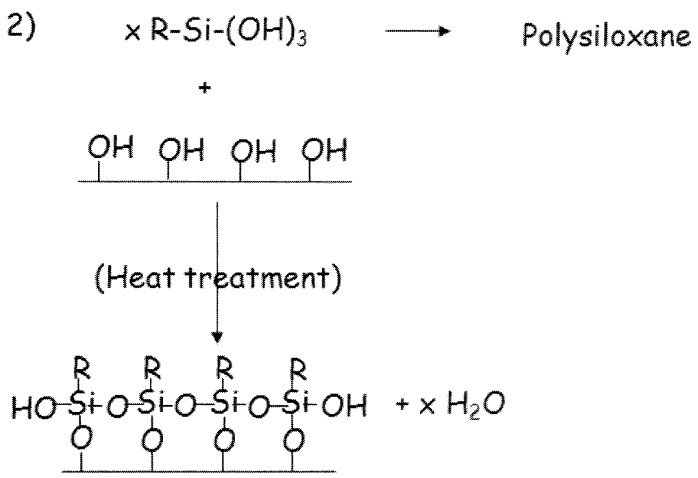

Fig. 1 シランカップリング剤の反応例

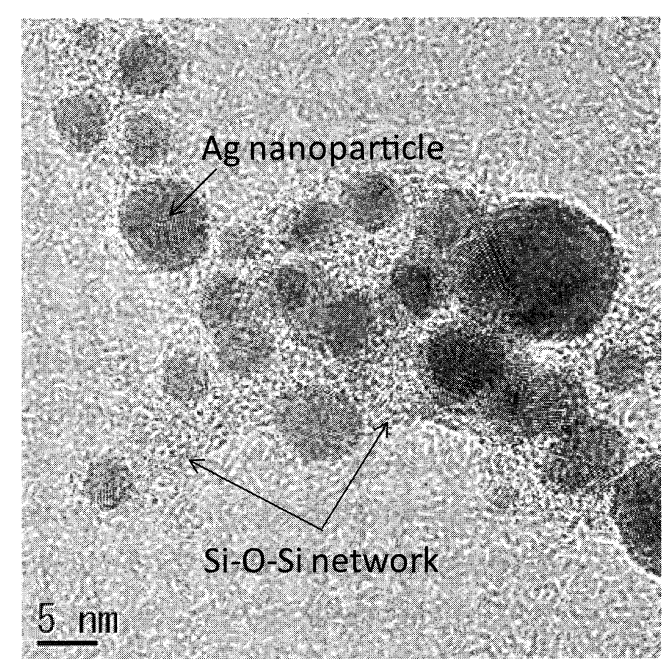

Fig. 2 シランカップリング処理した Agナノ粒子の TEM 観察像

子表面にシランカップリング処理を施した粒子の TEM 像を示す。適切な表面修飾条件下で修飾を行わないと,

Fig. 2 に示すように Ag 粒子間に Si-O-Si 構造に由来する 強い架橋構造が生成することになる。

この課題を解決するため, 筆者らは, 酸化物ナノ粒子 の液中分散性を維持したままシランカップリング剤で修

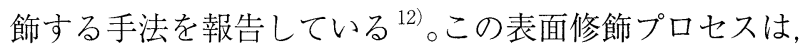
分散性水系ゾルを出発原料とし，シランカップリング剂 の過度な反応を抑制する溶媒条件や, シランカップリン グ剂の粒子への吸着過程と粒子表面とシランカップリン グ剂の反応過程を分けた点に特徴があり, プロセスの詳 細は既報をご参照いたたききたい ${ }^{12,13) 。 こ の フ ゚ ロ セ ス て ゙ ~}$ 修飾されたナノ粒子は, 粒子の乾燥処理後も簡単な超音 波処理によって表面修飾剤に依存した有機溶媒にその一 次粒子近くまで再分散が可能である。また, 複数種類の シランカップリング剤を用いた表面修飾によってナノ粒 子表面の化学構造を詳細に制御できることが明らかと なっている 12,14)。たとえば, Fig. 3 は有機官能基 R と してアルキル基 (疎水基) とアミノプロピル基（親水基） を有するシランカップリング剂を様々な比率で粒子表面 に固定化した $\mathrm{TiO}_{2}$ ナノ粒子をメタノールノトルエンの 混合溶媒に再分散させた際の平均粒子径を動的光散乱法 により評価した結果を示す。疎水基のみで修飾した粒子 は, トルエンに一次粒子近くまで再分散可能であり, 透 明性の高いサスペンションが得られた一方で，メタノー 儿混合比が増大し溶媒の極性が上昇するにつれて凝集径 が増大した。一方, 疎水基／親水基比がおよそ $1: 1$ で 固定化された $\mathrm{TiO}_{2}$ ナノ粒子はトルエンには再分散が困 難であったが, トルエン／メタノール混合溶媒中では均 一分散が可能であった。このように，シランカップリン グ剤の複合利用によってさまざまな極性の有機溶媒に対 


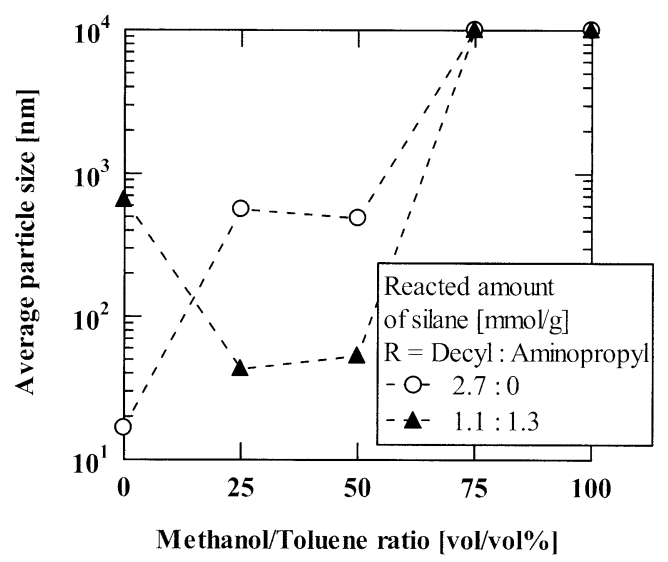

Fig. 3 デシル基およびアミノプロピル基を有するシラン カップリング剂で修飾した $\mathrm{TiO}_{2}$ ナノ粒子の混合有機 溶媒中に打ける平均凝集径 (動的光散乱法) ${ }^{12}$

して再分散できる表面設計法の可能性が示晙された。こ の結果をうけて，粒子表面に固定化された親水基／疎水 基比が再分散可能な有機溶媒種に及ぼす影響の整理を検 討した ${ }^{14)}$ 結果の一部を Fig. 4 に示す。親水基を有する シランカップリング剂としてアミノプロピルトリメトキ シシラン，疎水基を有するシランカップリング剤として デシルトリメトキシシランまたはフェニルトリメトキシ シランを用い, $\mathrm{TiO}_{2}$ ナノ粒子表面に結合したカップリ ング剤の比率が粒子の分散できる有機溶媒種に及ぼす影 響を示した。眓中の×印は回収した粒子の再分散が不可
能であり，固形分が沈澱する系，○および○印は粒子が 再分散可能であり動的光散乱法で評価した平均凝集系が それぞれ $50 \mathrm{~nm}$ 以上のものと $50 \mathrm{~nm}$ より小さいもので ある。低極性溶媒であるトルエンに再分散可能であるナ ノ粒子を設計する場合は, 疎水性の強いアルキル鎖など の有機官能基のみで表面を修飾することが必要であり， 疎水性官能基としてフェニル基を用いたり，表面にわず かにアミノプロピル基が導入されたりしてもトルエンに 再分散できなくなることが明らかとなった。一方，極性 の高いNMP などの溶媒に分散させるためには, 疎水性 有機官能基としてフェニル基を用いるか，アルキル基と アミノプロピル基を混合して利用することが効果的であ ることを示した。このような基礎データの蓄積によって 溶媒に応じた表面設計が実現可能である。

ナノ粒子の有機溶媒系への均一分散を目的とした場 合，上述したプロセスを用いたシランカップリング剂の 複合利用によって達成可能であるが，樹脂系材料への均 一分散を目的とする場合は多段の表面修飾が必要となる 場合がある。ナノ粒子に多段階の表面修飾を施す場合は 1 段目のシランカップリング処理の際に，2段階目で行 う反応の反応起点となる官能基を導入しながら，2段階 目の反応を起こす溶媒系に均一分散できるような表面設 計が求められ, Try \& Errorでのアプローチ手法では困 難性が高い。この様な場合も Fig. 4 で得られた基礎デー

(a)
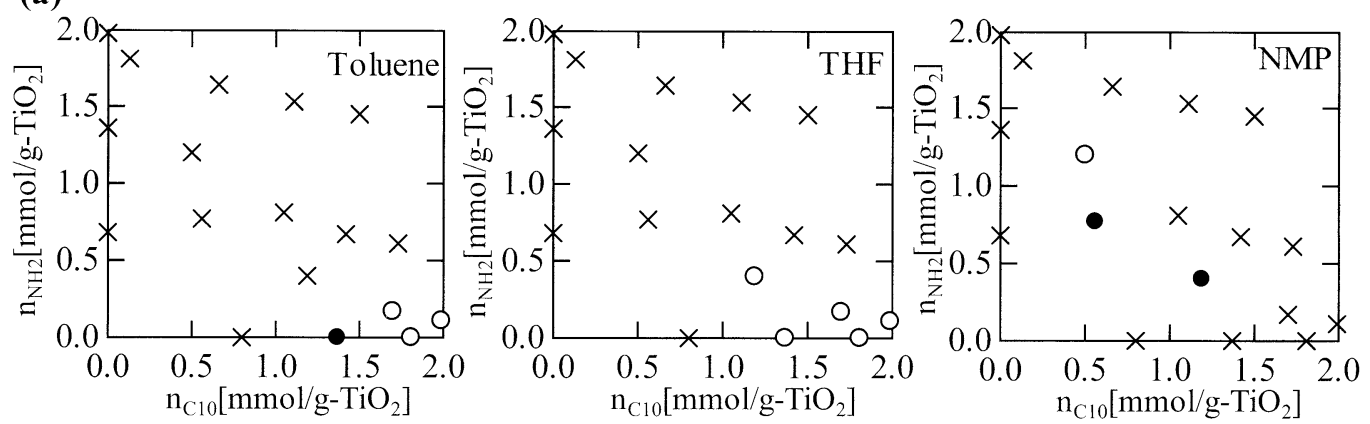

(b)
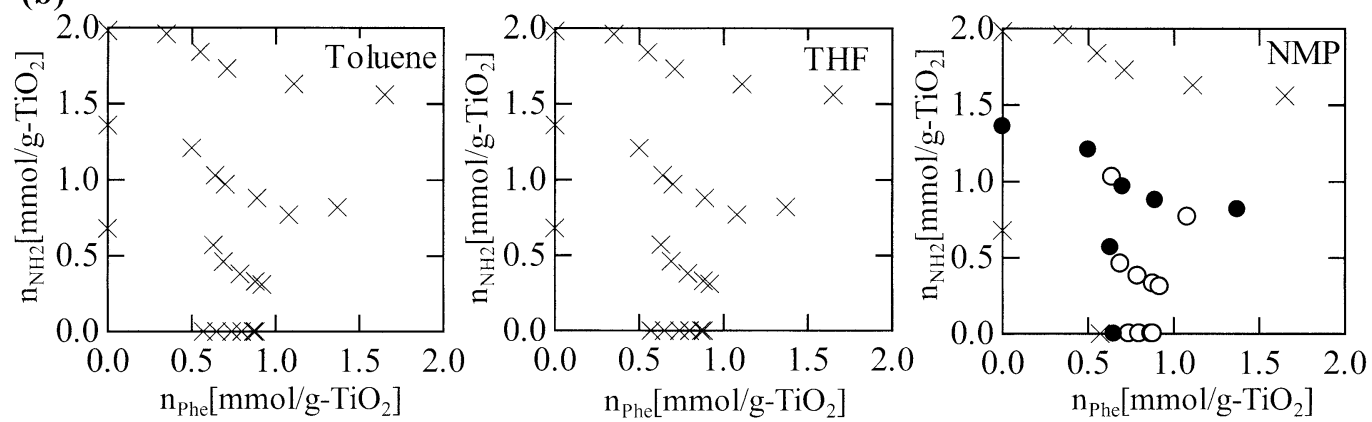

Fig. $4 \mathrm{TiO}_{2}$ ナノ粒子に修飾された親水性および疎水性官能基を有するシランカップリング剂の比率が各種溶媒中に㧍ける分散 特性に及ぼす影響。親水性官能基としてはアミノプロピル基，疎水性官能基としては（a）デシル基または（b）フェニル 基を用いた。×は粒子がまったく分散しない 均凝集径が $50 \mathrm{~nm}$ 以下であったことを示す ${ }^{14}$

はサスペンションの平均凝集径（動的光散乱法）が $50 \mathrm{~nm}$ 以上, ○は平 
夕が効果を発揮すると考えられ，とりわけアミノプロピ ル基と踈水基の比率でさまざまな極性の有機溶媒に再分 散できるように表面設計できる点が効果的である。アミ ノプロピル基は反応性に富む官能基であり，酸塩化物や エポキシ基, 環状酸無水物などと収率良く反応すること ができるため，ナノ粒子の分散性を維持しながら反応点 を粒子に固定化することが可能となる。Fig. 5 には一例 として，N-メチルピロリドン（NMP）に均一分散でき るようにアミノプロピル基とフェニル基を固定化した $\mathrm{TiO}_{2}$ ナノ粒子を対象に, NMP 中でテレフタル酸ジクロ リドを反応させた粒子の粒度分布を示す。多段階の表面 修飾過程において粒子が大きく凝集していないことが明 らかである。また，テレフタル酸ジクロリドの固定化は $\mathrm{TiO}_{2}$ ナノ粒子をポリアミド系樹脂に混合する際に有益 であり，テレフタル酸ジクロリドの固定化前の粒子は $\mathrm{TiO}_{2} / \mathrm{NMP}$ 溶液をポリアミド系樹脂に混合しただけで 凝集・白濁した一方で，テレフタル酸ジクロリドの固定 化によって凝集・白濁現象が抑制されている。

さて，上記で概説したシランカップリング処理や多段 階表面処理プロセスはいずれも出発原料として分散安定 性の高い水系酸化物ナノ粒子ゾルを用いた事例である。 しかし，現実には原料粒子の製造後に乾燥操作などに よって一度凝集してしまった粒子を分散する必要性にも 直面する。このようなナノ粒子に対しては凝集体を解砕, 一次粒子まで再分散させながら上記の表面修飾を行うこ とが重要である。近年，ナノ粒子の液中での物理的・機 械的手法による分散技術は著しく進歩している。その代 表的な手法が，直径 30 50 $\mu \mathrm{m}$ の微小球型セラミック ス球充填層を高速に攪拌するビーズミルがある ${ }^{15) 。 こ ~}$ の微小ビーズを使用することで一次粒子を粉砕すること なく凝集構造のみを破壊・分散することができる。この

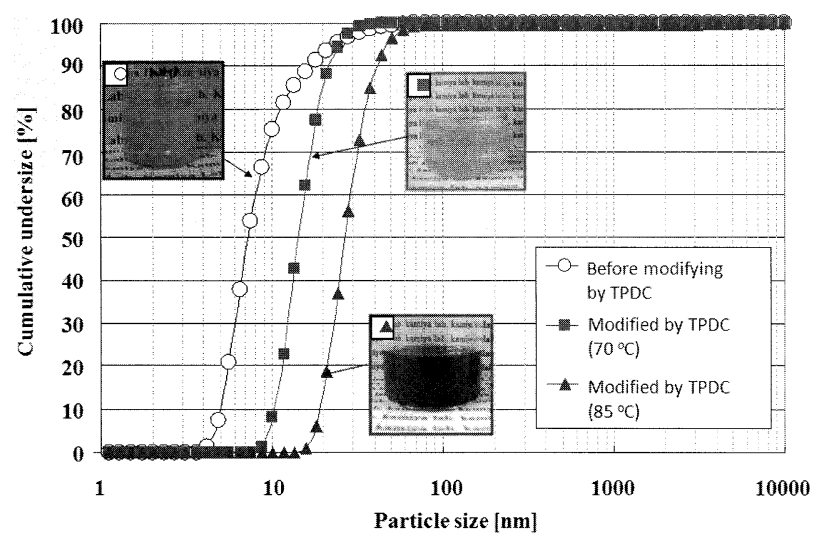

Fig. 5 フェニル基およびアミノ基を有するシランカップリ ング剤で修飾した $\mathrm{TiO}_{2}$ ナノ粒子にテレフタル酸ジク ロリド（TPDC）を修飾した粒子の NMP 中における 粒度分布
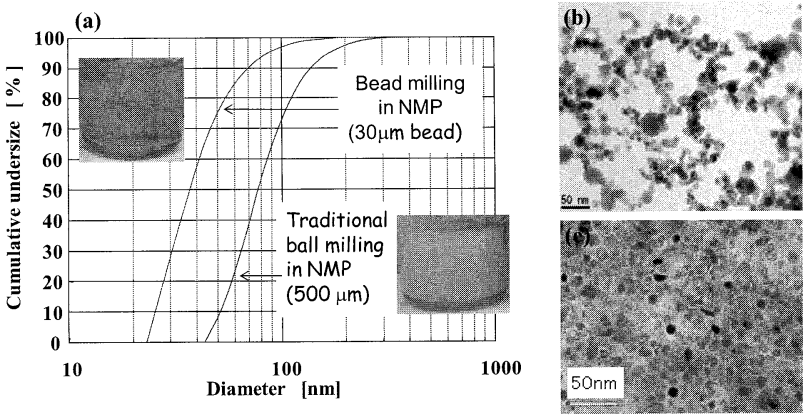

Fig. 6 気相プロセスで調製された $\mathrm{SiO}_{2} / \mathrm{TiO}_{2}$ 複合ナノ粒子 の物理的解砕処理とシランカップリング処理の同時 操作によるNMPへの分散。(a) ボールミルおよび ビーズミル処理した後のサスペンションの様子。(b) ビーズミル処理前および (c) ビーズミル処理後の $\mathrm{SiO}_{2} / \mathrm{TiO}_{2}$ 複合ナノ粒子の $\mathrm{TEM}$ 観察像

ほか, 高出力の超音波ホモジナイザーや液体ジェットミ ルを用いた方法もある。いずれの物理的・機械的プロセ スも，分散に時間を要する，粒子濃度に制限がある， ジェットミル以外ではビーズや容器からの不純物混入な どが課題として挙げられる。一方で, 大量処理が可能で あり，高温気相合成プロセスで得られた高結晶の粉末を 分散することができるなどの利点も多い。当研究グルー プでも気相プロセスで得られた $\mathrm{SiO}_{2} / \mathrm{TiO}_{2}$ 複合ナノ粒子 を対象に，ビーズミルと表面処理の同時操作による有機 溶媒への均一分散を検討している ${ }^{16)}$ 。表面修飾剂とし ては, Fig. 4 より NMPへの粒子分散にはフェニルトリ メトキシシランが有用であることが示されており，使用 した。Fig. 6 には，表面修飾と $30 \mu \mathrm{m}$ のビーズを用いた 解砕処理を同時に施したサスペンションと，500 $\mu \mathrm{m}$ の ボールでボールミル処理を同時に施したサスペンション の様子とそれぞれの粒度分布を示す。ビーズミル処理と 表面修飾によってサスペンションの凝集粒子径が数 $10 \mathrm{~nm}$ 程度まで低下し, 溶液の透明性も飛躍的に向上す ることが明らかとなっている。また，ビーズミル処理前 の粒子は鎖状の不均一な凝集構造を有していた一方で, ビーズミル処理後には粒子が解砕されたために, 電子顕 微鏡のグリッド上で乾燥時に粒子が均一にパッキングし た構造が観察された。

\section{3 機能性アニオン性界面活性剤を用いた分散制御}

これまではさまざまな有機官能基を有するシランカッ プリング剤を組み合わせた表面修飾や，多段階表面修飾 によって有機溶媒や樹脂中におけるナノ粒子の分散制御 法について紹介してきた。ナノ粒子を分散させる有機溶 媒に応じた適切な表面処理条件を整理することによって ナノ粒子の一次粒子近いサイズでの分散安定化が実現し ている。一方，ある任意の表面設計を施したナノ粒子が 
分散可能な溶媒種は，選択した表面修飾剤に依存した有 機溶媒にのみ分散可能であるため, 複合材料等を調製す る過程で複数の溶媒種を用いる必要がある場合は粒子凝 集の課題に直面する。このような課題を解決するため, 筆者らは有機鎖として末端に不飽和結合を有するポリエ チレングリコール鎖（親水鎖）とアルキル鎖（疎水鎖） が頭基付近で分岐した構造のリン酸系アニオン性界面活 性剂を表面修飾剂として利用する手法を報告している 17)。ポリエチレングリコール鎖は主に極性の高い有機溶 媒種, アルキル鎖は極性の低い有機溶媒種, 不飽和結合 はラジカル重合性のポリマーへの分散を意識した設計と なっている。この表面修飾剤を分散性 $\mathrm{TiO}_{2}$ ナノ粒子に 表面修飾して得られた粉末は, 乾燥処理後でもエ夕ノー ル, トルエン, NMP などの極性の大小によらない多く の有機溶媒に一次粒子近くまで再分散可能であった。さ らに, Fig. 7 に示すように, 全く異なる性質の樹脂であ るエポキシ樹脂やポリメチルメタクリレート樹脂ついて も，粒子の分散性を維持したまま高濃度分散が可能であ り, 透明性の高い複合体が得られている。これらの複合 体の透過電子顕微鏡による観察結果もあわせて Fig. 7 に 示しているが, $\mathrm{TiO}_{2}$ ナノ粒子の粗大凝集粒子は確認さ れず，高度に分散していることが観察される。

また，このような機能性アニオン性界面活性剤の頭基 としては, カルボン酸, 硫酸, リン酸系の界面活性剂が 挙げられ，粒子に充分量吸着させることによって高い分 散効果が得られる。しかし, 粒子材質と頭基の組み合わ せよっては充分に粒子表面に吸着しない場合もある。た とえば $\mathrm{SiO}_{2}$ ナノ粒子などは $\mathrm{TiO}_{2}$ ナノ粒子と比べてこれ らアニオン性界面活性剤の吸着性が極めて低い。このよ うな粒子の分散安定化については，カチオン性高分子分 散剤を吸着させた後にアニオン性界面活性剂を吸着させ

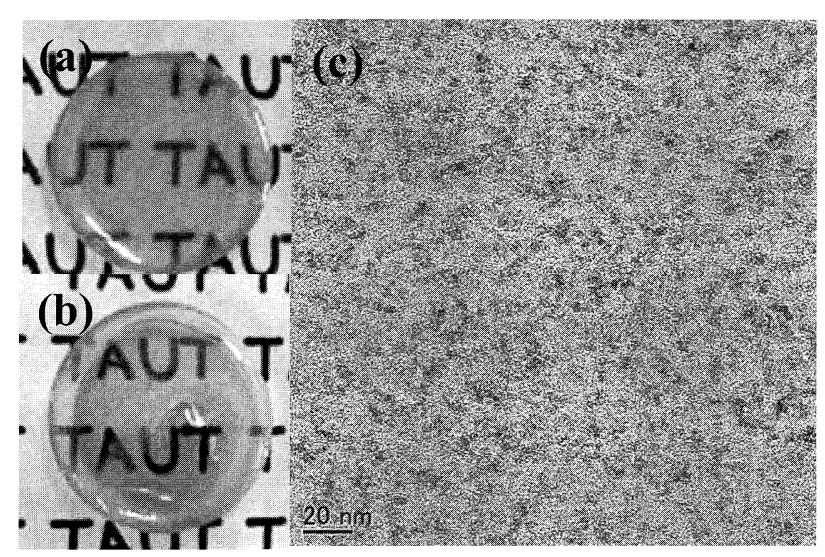

Fig. 7 親水鎖と疎水鎖に分岐したアニオン性界面活性剂で 修飾した $\mathrm{TiO}_{2}$ ナノ粒子を(a) エポキシ樹脂 $\left(\mathrm{TiO}_{2}\right.$ $13 \mathrm{wt} \%)$ および（b） PMMA 樹脂（ $\left.\mathrm{TiO}_{2} 6 \mathrm{wt} \%\right) に$ 分散させた複合体と（c）エポキシ $/ \mathrm{TiO}_{2}$ 複合体の TEM 観察像 ${ }^{17}$

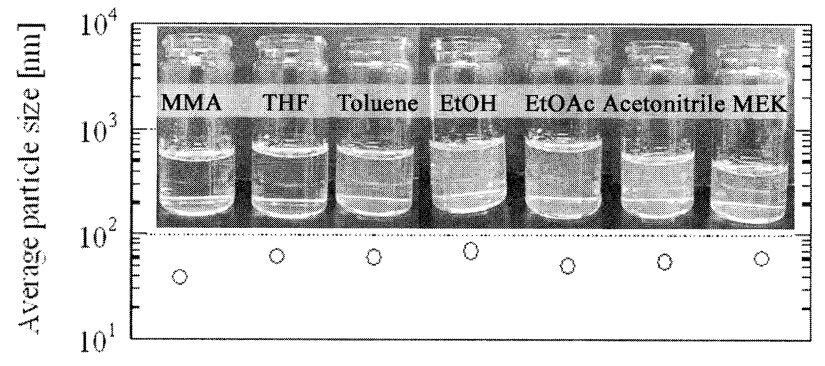

Fig. 8 ポリエチレンイミンを用いた交互吸着プロセスを用 いて親水鎖と疎水鎖に分岐したアニオン性界面活性 剤を修飾した $\mathrm{SiO}_{2}$ ナノ粒子の各種有機溶媒での分散 安定性 ${ }^{18)}$

る交互吸着プロセスが一つの解決法となる。たとえば, Fig. 8 にはカチオン性高分子分散剤としてポリエチレン イミンで修飾した後に，上述した親水鎖／疎水鎖分岐型 のアニオン性界面活性剂を吸着させた $30 \mathrm{~nm}$ の $\mathrm{SiO}_{2}$ ナ ノ粒子をさまざまな有機溶媒に再分散させた際の様子を 示す ${ }^{18)}$ 。得られたサスペンションに扔ける粒子の平均 径を動的光散乱法で評価した結果もあわせて同図に示し た。得られた $\mathrm{SiO}_{2}$ ナノ粒子は粉末として乾燥回収後で も，極性によらない多くの有機溶媒にその一次粒子径近 くまで再分散可能であることが確認され, $\mathrm{SiO}_{2}$ ナノ粒 子上に機能性界面活性剤が充分に吸着することで, 分散 機能が発現していることが確認された。 $\mathrm{SiO}_{2}$ ナノ粒子 に限らず，Agをはじめとした金属ナノ粒子についても， この交互吸着プロセスを用いた分散性ナノ粒子の調製が 可能であることを報告している。また，このような高分 子分散剤や，界面活性剂を用いた表面修飾においても， シランカップリング処理と同様に物理的解砕処理との同 時操作によって気相プロセスで得られたナノ粒子の高度 分散化が可能である。たとえば，カーボンブラック粒子 を対象に水中でポリエチレンイミンを吸着させる際に ビーズミル処理を行った粒子は, 数 $10 \mathrm{~nm}$ のサズで 液中に分散安定化させることができる。さらに上述の交 互吸着プロセスによって親水鎖/踈水鎖分岐型のア二オ ン性界面活性剤を吸着させることにより，多くの有機溶 媒に均一分散可能なカーボンブラック粒子の調製に成功 している ${ }^{19)}$ 。

\section{4 おわりに}

ナノ粒子の合成と同時に表面修飾を施すプロセスや, ナノ粒子の合成後に表面修飾を施すプロセスを用いるこ とで，さまざまな溶媒種や粒子種の組み合わせについて 粒子を均一に分散させることがそれほど困難ではなく なってきた。しかし，こうして得られたナノ粒子分散液 を原料としてさまざまな素材や複合材料に応用する際に は，ナノ粒子用の粉体プロセスの発展が必要である。た 
とえば，七ラミックス用に応用する際には，高濃度のサ スペンションをテープ成型などで成型した後, 乾燥, 焼 結などのプロセスを経るが, 成型後の乾燥・焼結過程で わずかでも成型体に密度むらがあると変形や割れなどが サブミクロン粒子よりも格段に生じやすい。また，ポリ マーなどに複合化させる用途についても，ナノ粒子を分 散安定化させるために修飾した有機物の占める割合が, ナノ粒子の高い比表面積に由来して非常に大きくなるた め, 複合化させた際に期待されるポリマーの機能が充分 に発現しない課題もある。この様な複合材料の実用化に 向けて，ナノ粒子の分散安定化技術をもとにナノ粒子に 適したプロセスの構築が求められる。

\section{文 献}

1) Nanoparticle Technolgy Handbook (M. Hosokawa, K. Nogi, M. Naito \& T. Yokoyama ed.), Elsevier, Amsterdam, Netherlands (2007).

2) Nanoparticle Handbok (M. Hosokawa ed., in Japanese), The Nikkan Kogyo Shimbun, Tokyo, Japan (2006).

3）（独）産業技術総合研究所：「ナノリスクに関するネッ トパネル事業」: http://www.aist-riss.jp/projects/nanorisknetpanel/

4) E. Verwey \& J. Th. G. Overbeek, Theory of the Stabil- ity of Lyophobic Colloids, Elsevier, Amsterdam, Netherlands (1948).

5) I. Capek, Adv. Colloid Interface Sci., 110, $49-74$ (2004).

6) C. Feldmann, Adv. Funct. Mater. 13, 101-7 (2003).

7) J. Park, K. An et al., Nature Mater. 3, 891-5 (2004).

8) H. A. Clark, E. P. Pluedemann, Modern plastics, 133-8 (1963).

9) M. Chainmberg, R. Parnas et al., J. Appl. Polym. Sci., 37, 2921-31 (1989).

10) N. R. Jana, C. Earhart et al., Chem. Mater. 19, 5074-82 (2007).

11) M. Iijima, M. Tsukada et al., J. Colloid Interface Sci. 305, 315-23 (2007)

12) M. Iijima, M. Kobayakawa et al., J. Colloid and Interface Sci., 337, 61-5 (2009).

13）飯島志行, 粉体工学会誌, 47 (7), 481-4 (2010).

14) M. Iijima, S. Takenouchi et al., Adv. Powder Technol., in press.

15) M. Inkyo, T. Tahara et al., J. Colloid and Interface Sci., 304, 535-40 (2007).

16）竹林賢治，笹辺修司ら，粉体工学会誌，47（5)，310-6 (2010)

17) M. Iijima, M. Kobayakawa et al., J. Am. Chem. Soc., 131, 16342-43 (2009).

18) M, Iijima \& H, Kamiya, Langmuir, 26, 17943-8 (2010).

19）山㟝美和, 飯島志行ら, 化学工学会第 76 年会講演要旨 集, L303 (2011) 